Www.jmscr.igmpublication.org Impact Factor 5.84

Index Copernicus Value: 83.27

ISSN (e)-2347-176x ISSN (p) 2455-0450

crossref DOI: https://dx.doi.org/10.18535/jmscr/v5i6.88

Journal Of Medical Science And Clinical Research

\title{
A Comparative Study of Intubating Conditions and Cardiovascular Effects of Rocuronium and Succinylcholine in Rapid Sequence Induction and Intubation
}

\author{
Authors \\ Ibemhal Heisnam ${ }^{1}$, K.Sarda Devi ${ }^{2}$, S.Thoibahenba Singh ${ }^{3}$, K. Upendra Singh ${ }^{4}$, \\ Rakesh Nongthombam ${ }^{5}$ \\ ${ }^{1,3,4}$ Associate Professor, ${ }^{2}$ Senior Resident, ${ }^{5}$ Assistant Professor \\ Department of Anaesthesia and Critical Care, JNIMS Imphal, Manipur \\ Corresponding Author \\ Dr Ibemhal Heisnam \\ Associate Professor, Department of Anaesthesiology and Critical Care \\ Jawaharlal Nehru Institute of Medical Sciences Imphal: - 795005 Manipur \\ Mobile no: 9856153557, E-mail: dribemhal@gmail.com
}

\begin{abstract}
Aim of Study: Succinylcholine is the most frequently used muscle relaxant for rapid sequence intubation but sometimes the need arises to use another agent. The aim of our study is to compare the haemodynamic profile and intubating conditions of rocuronium with that of succinylcholine during rapid sequence induction and intubation.

Material and Methods: 80 patients posted for emergency surgical procedure under general anaesthesia were randomly divided into two groups $A \& B$. A rapid sequence induction and intubation were done in all the patients. Group a patients received $0.6 \mathrm{mg} / \mathrm{kg}$ rocuronium and Group B received $1.5 \mathrm{mg} / \mathrm{kg}$ succinylcholine. Intubation was done at 60 seconds after the administration of muscle relaxant and intubating conditions was graded according to Copenhagen Consensus Conference Rating Scale. The haemodynamic parameters (pulse rate \& blood pressure) were recorded and compared.

Results: In both the groups pulse rate and blood pressure increases significantly just after intubation but the increase was not significant after 10 minutes. There was no significant difference regarding laryngoscopy, vocal cord relaxation and response to intubation in both the groups. Overall intubating conditions in group A and B were excellent in $77.5 \%$ and $82.5 \%$ while good in $20 \%$ and17.5\% patients respectively. Only one patient (2.5\%) in group A showed poor intubating condition. Clinically acceptable intubating conditions (excellent \& good) were comparable in both the groups.

Conclusion: Rocuronium $0.6 \mathrm{mg} / \mathrm{kg}$ provides clinically acceptable intubating conditions similar to succinylcholine $1.5 \mathrm{mg} / \mathrm{kg}$ at 60 second during rapid sequence induction and intubation with minimum haemodynamic variations.

Key Words: Rocuronium, succinylcholine, intubating condition, rapid sequence intubation.
\end{abstract}




\section{Introduction}

Rapid sequence induction and intubation (RSII) is the cornerstone of emergency airway management. The aim is to intubate the trachea as quickly and safely as possible. For this we require a fast acting inducing agent and a muscle relaxant to facilitate tracheal intubation and secure the airway. Succinylcholine is the time tested NMBA of choice of RSI because of its fastest onset (4560 seconds) and shortest duration of action (6-10 minutes) compared to all other agents ${ }^{1}$. But it is not devoid of side effects, some of which may be detrimental to the patients. Succinylcholine produces muscle fasiculations causing postoperative myalgia, increases intracranial, intraocular as well as intragastric pressure. Cardiovascular effects may include varied forms of arrhythmias especially bradyarrythmias and asystole. There is a risk of succinylcholine induced hyperkalemia in certain subsets of patients $^{2}$. Prolonged apnoea may also be encountered in patients with atypical pseudo cholinesterase. Considering all these side effects, succinylcholine cannot be used as the sole agent for RSI.

Rocuronium bromide has proven to be 5-7 times less potent than vecuronium with an $\mathrm{ED}_{95}$ of $0.3 \mathrm{mg} / \mathrm{kg}$ as compared to an $\mathrm{ED}_{95}$ of $0.056 \mathrm{mg} / \mathrm{kg}$ of vecuronium. This lack of potency is an important factor in determining the onset of neuromuscular block. It was found that the onset of action of rocuronium was 60-90 seconds at the adductor pollicis muscle, comparable with that of succinylcholine ${ }^{3}$. It is also devoid of many sideeffects encountered with succinylcholine. There is no evidence of histamine release, possesses a stable cardiovascular profile, can be used with ease in neurosurgical patients, penetrating eye injury, burn or hyperkalemic patients ${ }^{4}$, since there is no danger of increased ICP or IOP and hyperkalemia.

Considering the various attractive properties of rocuronium, the present study was undertaken to evaluate the intubating conditions and cardiovascular effects of rocuronium and compare it with succinylcholine during rapid sequence induction and intubation.

\section{Material and Methods}

After approval from the institutional ethical committee, 80 patients belonging to ASA I and II posted for emergency surgical procedures under general anaesthesia were included in the study. All the patients were explained about the purpose and procedure of the study and informed consent was obtained from them.

Inclusion criteria: Patients of either sex, aged between 20-60 yrs, ASA grade I\&II and Mallampati grade I\&II.

Exclusion Criteria: Patients with ASA grade III and IV, Mallampati grade III and IV, patients with neuromuscular disease, family history of malignant hyperthermia, allergy to succinylcholine and rocuronium.

All the 80 patients were randomly divided into two groups A and B of 40 each. A thorough preanaesthetic check-up was done before shifting the patients to the emergency theatre and minimum baseline investigations which include $\mathrm{Hb} \%, \mathrm{CBC}$, blood sugar, blood group, ECG and X- ray chest were done. Serum electrolytes, LFT and blood gas analysis were done whenever indicated.

On arrival in the operative room, baseline pulse rate, blood pressure and $\mathrm{SpO}_{2}$ were recorded. All the patients were premedicated with $4 \mathrm{mg}$ IV ondenesetron and $0.2 \mathrm{mg}$ IM glycopyrrolate. After preoxygenation for 3 minutes, a rapid sequence induction with thiopentone sodium (2.5\%), $5 \mathrm{mg} / \mathrm{kg}$ was done. After the abolition of eyelash reflex, group a patients received $0.6 \mathrm{mg} / \mathrm{kg}$ rocuronium and group $B$ received $1.5 \mathrm{mg} / \mathrm{kg}$ succinylcholine. At 60 seconds, laryngoscopy was done and the intubating conditions were assessed by a trained anaesthetist. Cricoid pressure was applied and maintained till airway was secured with adequate size cuffed endotracheal tube. Anaesthesia was maintained with $\mathrm{N}_{2} \mathrm{O}$ and $\mathrm{O}_{2}$ mixture and intermittent injection of vecuronium. Analgesics and isoflurane were given as per need and condition of the patient. At the end of surgery, 
neuromuscular blockade was reversed by neostigmine and glycopyrrolate. After the return of adequate respiratory effort and upper airway reflexes and spontaneous eye opening, extubation was done and then the patients were shifted to the recovery room.

\section{Parameters Observed}

1. Cardiovascular response - Pulse rate and blood pressure were recorded immediately after intubation and 10 minutes later.

\section{Intubating conditions -}

- Laryngoscopy : Jaw relaxation.

- Vocal cords: Position and movement.

- Response to intubation: Coughing and limb movement.

Intubating conditions were graded as excellent, good and poor according to the grading scale described by International Consensus Conference held in Copenhagen in 1994. (Copenhagen Consensus Conference Rating Scale) Table 1a. Excellent and good intubating conditions are taken as clinically acceptable.

Table 1a: Copenhagen Consensus Conference Rating Scale

\begin{tabular}{|l|c|c|c|}
\hline \multirow{2}{*}{$\begin{array}{l}\text { Intubating } \\
\text { Conditions Variables }\end{array}$} & \multicolumn{2}{|c|}{ Clinically Acceptable } & $\begin{array}{c}\text { Clinically } \\
\text { Unacceptable }\end{array}$ \\
\cline { 2 - 4 } & Excellent & Good & Poor \\
\hline Laryngoscopy & Easy & Fair & Difficult \\
\hline Vocal Cords & & & Closed \\
\hline Position To & Abducted & Intermediate & Vigorous \\
\hline Movement & & Moving & \\
\hline $\begin{array}{l}\text { Response } \\
\text { Intubation }\end{array}$ & None & Slight & Vigorous \\
\hline Movement Of Limbs & None & Diaphragmatic & Sustained (>10s) \\
\hline Coughing & & & \\
\hline
\end{tabular}

\section{Laryngoscopy:}

Easy: Jaw relaxed, no resistance to blade in the course of laryngoscopy.

Fair: Jaw relaxed, slight resistance to the blade.

Difficult: Poor jaw relaxation, active resistance of the patient to laryngoscopy.

\section{Intubating Conditions:}

Excellent: All variable listed under excellent must be present.

Good: Only variable listed under excellent or good must be present.
Poor: The presence of any variable listed under poor.

Clinically acceptable: excellent and good

\section{Observations and Results}

The study included 80 patients, 40 in each group. The mean age in years in group $\mathrm{A}$ is $32.5 \pm 1.414$ and in group B is $32.4 \pm 1.457$. The mean weight is $49.55 \pm 6.90 \mathrm{kgs}$ and $49.47 \pm 5.91 \mathrm{kgs}$ respectively in group $\mathrm{A}$ and $\mathrm{B}$. The sex ratio $(\mathrm{M} / \mathrm{F})$ is 0.81 in group $\mathrm{A}$ and 1.10 in group B. There were no significant demographic differences among the groups with respect to age, sex and weight. $(\mathrm{P}>0.05)$ Table $1 \mathrm{~b}$.

Table -1b: Demographic Variables of Patients

\begin{tabular}{|l|c|c|}
\hline Parameters & Group A & Group B \\
\hline Age (yrs) & $32.5 \pm 1.414$ & $32.4 \pm 1.457$ \\
Mean \pm SD & & \\
\hline Weight $($ Kgs) & $49.55 \pm 6.90$ & $49.4 \pm 5.91$ \\
Mean \pm SD & & \\
\hline Sex Ratio (M/F) & $9 / 11(0.81)$ & $21 / 19(1.10)$ \\
\hline
\end{tabular}

Regarding the hemodynamic variables, there was a definite increase in the mean pulse rate immediately after intubation which settled near its basal value 10 minutes later in both the groups. (Table 2a).

Table - 2(A) Mean Pulse Rate (Beats/Minute)

\begin{tabular}{|l|c|c|}
\hline Time & $\begin{array}{c}\text { Group A } \\
\text { Mean } \pm \text { SD }\end{array}$ & $\begin{array}{c}\text { Group B } \\
\text { Mean } \pm \text { SD }\end{array}$ \\
\hline Pre - Operative( Basal) & $90.20 \pm 8.50$ & $88.08 \pm 6.89$ \\
\hline $\begin{array}{l}\text { Immediately after } \\
\text { intubation }\end{array}$ & $101.90 \pm 9.71$ & $97.15 \pm 6056$ \\
\hline 10 minutes after intubation & $91.40 \pm 6.11$ & $89.45 \pm 4.90$ \\
\hline
\end{tabular}

The variation in the pulse rate between the preoperative values and that immediately after intubation was highly significant but was not significant when compared with values, 10 minutes after intubation (Table $2 b$ ).

Table - 2 (B): Test of Significance In Pulse Rate (Paired T Test)

\begin{tabular}{|c|c|c|c|c|}
\hline Group & Comparison between groups & d.f. & $\mathrm{t}$ & Inference \\
\hline \multirow[t]{2}{*}{$\begin{array}{l}\text { Group } \\
\text { A }\end{array}$} & $\begin{array}{l}\text { Pre- operative } \begin{array}{l}\text { and } \\
\text { immediately } \\
\text { intubation. }\end{array} \\
\text { after } \\
\end{array}$ & 39 & 15.332 & $\begin{array}{l}\text { Highly } \\
\text { significant }\end{array}$ \\
\hline & $\begin{array}{l}\text { Pre- operative and } 10 \\
\text { minutes after intubation. }\end{array}$ & 39 & 1.226 & $\begin{array}{l}\text { Not } \\
\text { significant }\end{array}$ \\
\hline \multirow[t]{2}{*}{$\begin{array}{l}\text { Group } \\
\text { B }\end{array}$} & $\begin{array}{lr}\text { Pre }- \text { operative } & \text { and } \\
\text { immediately } & \text { after } \\
\text { intubation. } & \end{array}$ & 39 & 11.903 & $\begin{array}{l}\text { Highly } \\
\text { significant }\end{array}$ \\
\hline & $\begin{array}{l}\text { Pre- operative and } 10 \\
\text { minutes after intubation. }\end{array}$ & 39 & 1.984 & $\begin{array}{l}\text { Not } \\
\text { significant }\end{array}$ \\
\hline
\end{tabular}


There was significant rise in both the systolic and diastolic blood pressure just after intubation but the rise was not significant when compared with values, after 10 mins. (Table $3 a$ \&b, Table 4a \& b). This increase is due to the pressure response during laryngoscopy and intubation.

Table 3 (A): Mean Systolic Blood Pressure (Mmhg)

\begin{tabular}{|l|c|c|}
\hline Time & $\begin{array}{c}\text { Group A Mean } \pm \\
\text { SD }\end{array}$ & $\begin{array}{c}\text { Group B Means } \pm \\
\text { SD }\end{array}$ \\
\hline Pre-operation & $124.35 \pm 8.08$ & $125.10 \pm 8.10$ \\
\hline $\begin{array}{l}\text { Intermediately after } \\
\text { intubation }\end{array}$ & $144.75 \pm 10.01$ & $148.30 \pm 8.33$ \\
\hline $\begin{array}{l}10 \quad \text { minutes after } \\
\text { intubation }\end{array}$ & $124.75 \pm 6.62$ & $125.63 \pm 7.84$ \\
\hline
\end{tabular}

Table 3 (b): Test of Significance in Systolic Blood Pressure (Paired' Test)

\begin{tabular}{|c|c|c|c|c|}
\hline Group & $\begin{array}{l}\text { Comparison } \\
\text { between groups }\end{array}$ & d.f. & $\mathrm{t}$ & Inference \\
\hline \multirow{2}{*}{$\begin{array}{l}\text { Group } \\
\text { A }\end{array}$} & $\begin{array}{l}\text { Pre-operative and } \\
\text { immediately after } \\
\text { intubation }\end{array}$ & 39 & 23.40 & $\begin{array}{l}\text { Highly } \\
\text { significant }\end{array}$ \\
\hline & $\begin{array}{l}\text { Pre-operative and } \\
10 \text { minutes after } \\
\text { intubation }\end{array}$ & 39 & 0.431 & $\begin{array}{l}\text { Not } \\
\text { significant }\end{array}$ \\
\hline \multirow{2}{*}{$\begin{array}{l}\text { Group } \\
\text { B }\end{array}$} & $\begin{array}{l}\text { Pre-operative and } \\
\text { immediately after } \\
\text { intubation }\end{array}$ & 39 & 21.790 & $\begin{array}{l}\text { Highly } \\
\text { significant }\end{array}$ \\
\hline & $\begin{array}{l}\text { Pre-operative and } \\
10 \text { minutes after } \\
\text { intubation }\end{array}$ & 39 & 1.121 & $\begin{array}{l}\text { Not } \\
\text { significant }\end{array}$ \\
\hline
\end{tabular}

Critical value of 't' at significance level, $0.05=2.020 .01=2.71$

Table 4 (a): MEAN DIASTOLIC BLOOD PRESSURE (MMHG)

\begin{tabular}{|l|l|l|}
\hline Time & $\begin{array}{l}\text { Group A Mean } \\
\pm \text { SD }\end{array}$ & $\begin{array}{l}\text { Group B Means } \pm \\
\text { SD }\end{array}$ \\
\hline Pre-operation after & $78.10 \pm 4.57$ & $79.55 \pm 4.97$ \\
\hline $\begin{array}{l}\text { Intermediately } \\
\text { intubation }\end{array}$ & $90.15 \pm 4.52$ & $90.00 \pm 5.10$ \\
\hline $\begin{array}{l}10 \quad \text { minutes after } \\
\text { intubation }\end{array}$ & $78.65 \pm 3.58$ & $80.23 \pm 4.54$ \\
\hline
\end{tabular}

Table 4 (b): Test of Significance in Diastolic Blood Pressure (Paired' Test)

\begin{tabular}{|c|c|c|c|c|}
\hline Group & $\begin{array}{l}\text { Comparison } \\
\text { between groups }\end{array}$ & d.f. & ' $\mathrm{t}$ ' & Inference \\
\hline \multirow{2}{*}{$\begin{array}{l}\text { Group } \\
\text { A }\end{array}$} & $\begin{array}{l}\text { Pre-operative and } \\
\text { immediately after } \\
\text { intubation }\end{array}$ & 39 & 12.702 & $\begin{array}{l}\text { Highly } \\
\text { significant }\end{array}$ \\
\hline & $\begin{array}{l}\text { Pre-operative and } \\
10 \text { minutes after } \\
\text { intubation }\end{array}$ & 39 & 1.215 & $\begin{array}{l}\text { Not } \\
\text { significant }\end{array}$ \\
\hline \multirow{2}{*}{ Group B } & $\begin{array}{l}\text { Pre-operative and } \\
\text { immediately after } \\
\text { intubation }\end{array}$ & 39 & 15.947 & $\begin{array}{l}\text { Highly } \\
\text { significant }\end{array}$ \\
\hline & $\begin{array}{l}\text { Pre-operative and } \\
10 \text { minutes after } \\
\text { intubation }\end{array}$ & 39 & 1.226 & $\begin{array}{l}\text { Not } \\
\text { significant }\end{array}$ \\
\hline
\end{tabular}

There was no statistical difference in laryngoscopy in both the groups as all the patients provides easy laryngoscopy (Table 5).

Table 5:_Laryngoscopy

\begin{tabular}{|l|c|c|c|c|}
\hline \multirow{2}{*}{ Parameter } & \multicolumn{2}{|c|}{ Group A } & \multicolumn{2}{c|}{ Group B } \\
\cline { 2 - 5 } & No. & $\%$ & No. & $\%$ \\
\hline Easy & 40 & 100 & 40 & 100 \\
\hline Fair & 0 & 0 & 0 & 0 \\
\hline Difficult & 0 & 0 & 0 & 0 \\
\hline
\end{tabular}

The vocal cords were abducted in $87.5 \%$, intermediate position in $10 \%$ and closed in $2.5 \%$ of the patients in group A. In group B, 95\% showed abducted vocal cords and 5\% showed intermediate position (Table 6a).

Table 6 (a): Position of Vocal Cords

\begin{tabular}{|l|c|c|c|c|}
\hline \multirow{2}{*}{ Parameter } & \multicolumn{2}{|c|}{ Group A } & \multicolumn{2}{c|}{ Group B } \\
\cline { 2 - 5 } & No. & $\%$ & No. & $\%$ \\
\hline Abducted & 35 & 87.5 & 38 & 95 \\
\hline Intermediate & 4 & 10 & 2 & 5 \\
\hline Closed & 1 & 2.5 & 0 & 0 \\
\hline
\end{tabular}

In group A, there was no movement of vocal cord in $95 \%$ of the patients while $5 \%$ showed moving cords. There was no movement of the vocal cord in all the patients (100\%) in group B (Table 6b).

Table 6 (b): Movement of Vocal Cords

\begin{tabular}{|l|c|c|c|c|}
\hline \multirow{2}{*}{ Parameter } & \multicolumn{2}{|c|}{ Group A } & \multicolumn{2}{c|}{ Group B } \\
\cline { 2 - 5 } & No. & $\%$ & No. & $\%$ \\
\hline None & 38 & 95 & 40 & 100 \\
\hline Moving & 2 & 5 & 0 & 0 \\
\hline Closing & 0 & 0 & 0 & 0 \\
\hline
\end{tabular}

In response to intubation, movement of limbs and coughing were monitored. In group a, 85\% showed no movement while $15 \%$ had slight movement of limbs. In group B, 95\% had no movement and 5\% showed slight movement? (7a) Table 7 (a): Response to Intubation (Movement Of Limbs)

\begin{tabular}{|l|c|c|c|c|}
\hline \multirow{2}{*}{ Parameter } & \multicolumn{2}{|c|}{ Group A } & \multicolumn{2}{c|}{ Group B } \\
\cline { 2 - 5 } & No. & $\%$ & No. & $\%$ \\
\hline None & 34 & 85 & 38 & 95 \\
\hline Slight & 6 & 15 & 2 & 5 \\
\hline Vigorous & 0 & 0 & 0 & 0 \\
\hline
\end{tabular}

Regarding coughing in in response to intubation, there was no coughing in $92.5 \%$ of the patients in group a while in group B, it was $97.5 \%$. $7.5 \%$ patients in group A and $2.5 \%$ patients in group B experience some diaphragmatic movement. (Table7b). 
Table 7 (b): Response to Intubation (Coughing)

\begin{tabular}{|l|c|c|c|c|}
\hline \multirow{2}{*}{ Parameter } & \multicolumn{2}{|c|}{ Group A } & \multicolumn{2}{c|}{ Group B } \\
\cline { 2 - 5 } & No. & $\%$ & No. & $\%$ \\
\hline None & 37 & 92.5 & 39 & 97.5 \\
\hline Diaphragm & 3 & 7.5 & 1 & 2.5 \\
\hline Sustained & 0 & 0 & 0 & 0 \\
\hline
\end{tabular}

There was no sustained coughing in any of the patients in both the groups. Considering the above parameters intubating conditions were graded as excellent, good and poor. $77.5 \%$ (31/40) patients in group a, 82.5\% (33/40) in group B showed excellent intubating conditions. There was good intubating conditions in 20\% (8/40) of the patients in group A and $17.5 \%$ (7/40) in group B. Only $2.5 \%(1 / 40)$ in group A showed poor intubation condition. None of the patients in group B had poor intubating condition (Table 8).

Table 8: Intubating Conditions

\begin{tabular}{|l|c|c|c|c|}
\hline \multirow{2}{*}{ Parameter } & \multicolumn{2}{|c|}{ Group A } & \multicolumn{2}{c|}{ Group B } \\
\cline { 2 - 5 } & No. & $\%$ & No. & $\%$ \\
\hline Excellent & 31 & 77.5 & 33 & 82.55 \\
\hline Good & 8 & 20 & 7 & 17.5 \\
\hline Poor & 1 & 2.5 & 0 & 0 \\
\hline
\end{tabular}

\section{Discussion}

Succinylcholine is the most reliable muscle relaxant during a rapid sequence induction and intubation. But sometimes an alternative drug may be required which provide acceptable intubation condition equivalent to that of succinylcholine during RSI. In our study, rocuronium $0.6 \mathrm{mg} / \mathrm{kg}$ provide clinically acceptable (excellent + good) intubating conditions at 60 seconds compared to $1.5 \mathrm{mg} / \mathrm{kg}$ succinylcholine similar to the observation of the study carried by Huizinga ${ }^{5}$ et al.

During an emergency procedure haemodynamic parameters are of paramount importance and we usually prefer drugs which are heamodynamically stable. In our study, both the groups (A \& B) shows a significant increase in heart rate and blood pressure (systolic \& diastolic) just immediately after intubation, then settled near its basal value within $10 \mathrm{~min}$. This may be due to pressor response during laryngoscopy since we did not use any drugs to attenuate the pressor response. Moreover opioid analgesics were avoided before intubation since it may depressed the laryngeal reflex and may augment vocal cord relaxation. Recuronium, in doses up to $1.2 \mathrm{mg} / \mathrm{kg}$ has minimal cardiovascular effects both in healthy patients and those with cardiovascular disease ${ }^{6}$. Intubating condition can be influenced by the choice of anaesthetic and use of adjuvant drugs, narcotics and sedatives. We selected thiopentone as the inducing agent as propofol depresses pharyngeal and laryngeal reflexes. We avoided giving analgesics or sedative prior to intubation as these agents may act as confounding factors in the evaluation. In our study, intubation was attempted at 60 seconds and scores were graded according to Copenhagen Consensus Conference Rating Scale. All the patients in succinylcholine group while 39 patients $(97 \%)$ in rocuronium group showed clinically acceptable (excellent + good) intubating conditions. Shukla ${ }^{7}$ et al in their study mentioned that rocuronium $0.6 \mathrm{mg} / \mathrm{kg}$ produce acceptable intubating condition in $80 \%$ of their patients. Larsen $\mathrm{PB}^{8}$ et al concluded that both rocuronium $0.6 \mathrm{mg} / \mathrm{kg}$ and succinylcholine $1.0 \mathrm{mg} / \mathrm{kg}$ provides clinically acceptable intubation in 60secs in patients scheduled for emergency surgery. Pery ${ }^{9}$ et al in a Cochrane Review analysed 24 studies and concluded that although succinylcholine provides more excellent intubating conditions than rocuronium but clinically acceptable conditions were not statistically different. These observations were comparable with the results of our study. The reason for lesser excellent intubating score with rocuronium was movement of vocal cords. There were some diaphragmatic movement and coughing as a response to intubation, but all these occurs after the placement of endotracheal tube, so the safety of patient was not compromised. Ali $\mathrm{A}^{10}$ et al in their study showed that rocuronium $1.0 \mathrm{mg} / \mathrm{kg}$ provides equally good intubating conditions compared to succinylcholine $1.5 \mathrm{mg} / \mathrm{kg}$ in elective caesarean section using RSI in 60secs. Rawle $\mathrm{A}^{11}$ et al in their Evidence-based Emergency Medicine Clinical Synopsis recommend succinylcholine as the agent of choice for RSI, except in those conditions where it is contraindicated. Belekar ${ }^{12}$ et al also suggested that succinylcholine is still the best short acting 
relaxant to accomplish RSI, however rocuronium may be used as in alternative to it in adequate doses at 60 seconds. Tran $\mathrm{DTT}^{13}$ et al in Cochrane review updated in 2015, found that rocuronium is slightly less effective than succinylcholine for creating excellent intubating conditions and should therefore only be used as an alternative to succinylcholine whenever it is contraindicated. In the study conducted by Syed Manzar $^{14}$ et al, they found that $90 \%$ patients were intubated after $0.6 \mathrm{mg} / \mathrm{kg}$ rocuronium at 60 seconds, comparable with the results of our study. Lata D. Shetty ${ }^{15}$ in their study concluded that rocuronium $(0.6 \mathrm{mg} / \mathrm{kg})$ produces excellent intubating conditions with minimum haemodynamic response and would be suitable for RSI condition. In our study also rocuronium provides equally good intubating condition comparable with succinylcholine at 60 seconds. No other side effects were encountered during the study.

\section{Conclusion}

We found that during rapid sequence induction and intubation both rocuronium $0.6 \mathrm{mg} / \mathrm{kg}$ and succinylcholine $1.5 \mathrm{mg} / \mathrm{kg}$ provides clinically acceptable (excellent + good) intubating conditions at 60 seconds with minimum haemodyanamic variation.

\section{References}

1. Schneider RE, Caro DA. Neuromuscular blocking agents. In: Walls RM, ed. Manual of Emergency Medicine Airway. $2^{\text {nd }}$ ed. Philadelphia, PA : Lippincott Williams \& Wilkins :2004

2. Martyn JAJ, Richtsfeld M. Succinylcholine induced hyperkalemia in acquired pathologic states: etiologic factors and molecular mechanisms. Anaesthesiology 2006; 104:158-159.

3. Cooper RA and Crawford JS (1992). Comparison of intubating conditions after administration of Org 9246(rocuronium) and suxamethonum. British Journal of Anaesthesia 69, 269 - 273.
4. Han TH, Martyn JA Onset and effectiveness of rucoronium for rapid onset of paralysis in patients with major burns priming or large bolus .Br.J. Anaesth. 2009; 102:55-60.

5. Huizinga ACT, Vandenbrom RH, Wierda JM, Homnes FD, Hennis PJ. Intubating conditions and onset of Neuromuscular block of Rocuronium (ORG 9426): A comparison with suxamethonium. Acta Anaesthesiol Scand 1992 July;36(5): 46368.

6. Levy Th. Davis G.K, Duggan J, Szlam, F Determination of the haemodynamics and histamine release of rocuronium (Org 9426) when administered in increased dose under $\mathrm{N}_{2} \mathrm{O} / \mathrm{O}_{2}$ - sufentanil anaesthesia Anaesthesia Analgesia 1994;78:318 - 321.

7. Shukla A, Dubey KP, Sharma MSN, Comparative evolution of Haemodynamics effects and intubating conditions after administration of Org 9426(Rocuronium) and Succinylcholic Indian J Anaesthesia 2004;48(6):476-79.

8. Larsen PB, Hensen EG, Jacobsen LS, Wiis J, Holst P et al. Intubating conditions after Rocuronium or Succinylcholine for rapid sequence intubation with alfentanial and propofol in the emergency patient. Eur $\mathbf{J}$ Anaesthesiology 2005 Oct; 22(10):748-53.

9. Pery J, Lee J, and Wells G. Rocuronium versus succinylcholine for rapid sequence induction .Cochrane Database Sys Rev.2003 ;( 1): CD 002788.

10. Ali A, Sheikh N A ,Khwaja S, Saleem J and Kaul SU. Comparision of Intubating conditions produced by Rcuronium and suxamethonium for Rapid Sequence Induction in Elective Caeseran.Annals Vol 14.No 1 Jan-Mar,2008:5-7.

11. Rawle A .Seupaul, James H , Jones. Does succinylcholine maximize intubating conditions better than rocuronium for rapid sequence intubation? Annals of 
Emergency Medicine.Volume57, No3:

March 2011:301-302.

12. Virendrakumar R Belekar ,Khamankar Rocuronium for Tracheal Intubation in patients undergoing emergency Surgery.IJPR Volume 3 Issue (2) 2013:18-

13. Tran DTT, Newton EK, Mount VAH ,Lee JS, Wells GA, Perry JJ. Rocuronium versus succinylcholine for rapid sequence induction intubation (Review): Cochrane Database of systemic Review 2015, Issue 10 Art No: CD 002788.

14. Syed Manzar Hassan, Sameer Ahmed A. Comparision between intubating conditions of succinylcholine and rocuronium bromide. International Journal of Basic and Applied Medical Sciences, 2016 Vol.6(2) May-August pp.12-17.

15. Lata D. Shetty Comparision of intubating conditions of succinylcholine with that of rocuronium. CIB Tech Journal of Pharmaceutical Sciences 2014 Vol.3 JulySeptember;23-27. 